DOI: 10.17516/1997-1370-0876

УДК 730

\title{
Polychromy in Modern Russian Sculpture
}

\author{
Marina V. Moskaliuk and Ilya V. Tsarinnyy* \\ Dmitri Hvorostovsky Siberian State Academy of Arts \\ Krasnoyarsk, Russian Federation
}

Received 10.10.2021, received in revised form 10.12.2021, accepted 18.01.2022

\begin{abstract}
This publication analyzes the possibilities of using polychromy in the creative practice of Russian sculptors. The emphasis is on highlighting the main criteria for the use of color. Hermeneutical and analytical approaches are used in combination with induction and comparison. In general, formal stylistic analysis prevails in the research methodology. The novelty of the study is due to the low level of study of the work of Russian sculptors and the weak elaboration of the problem of polychromy in the theory of sculpture as a whole.

Having briefly demonstrated the experience of using polychromy in sculpture throughout the history of the development of world cultures, the authors, based on the analysis of modern sculptural compositions, draw conclusions about the relevance and diversity of the use of polychromy in domestic sculpture of the twenty-first century. Two functions of using color in sculpture are highlighted, namely: imitation/animation and symbolic/ sacred. The characteristics of these functions are considered on the basis of concrete examples, in conclusion, the prospects for the development of polychromy as one of the most expressive compositional techniques of plastics are evaluated.
\end{abstract}

Keywords: polychromy, modern sculpture, easel sculpture, color in sculpture, semantics of color, sculptural materials, imitation/animation function, symbolic/sacred function.

Research area: art history.

Citation: Moskaliuk M. V., Tsarinnyy I. V. (2022). Polychromy in modern russian sculpture. J. Sib. Fed. Univ. Humanit. soc. sci., 15(1), 61-74. DOI: 10.17516/1997-1370-0876

(C) Siberian Federal University. All rights reserved

* Corresponding author E-mail address: ilya@tsarinny.ru 


\title{
Полихромия в современной российской скульптуре
}

\author{
М.В. Москалюк, И.В. Царинный \\ Сибирский государственный институт искусств \\ имени Дмитрия Хворостовского \\ Российская Федерачия, Красноярск
}

\begin{abstract}
Аннотация: В данной публикации анализируются возможности употребления полихромии в творческой практике российских скульпторов. Акцент сделан на выделение основных критериев использования цвета. Применяются герменевтический и аналитический подходы в сочетании с индукцией и сравнением. В целом в методологии исследования преобладает формально-стилистический анализ. Новизна исследования обусловлена малой изученностью творчества российских скульпторов и слабой проработанностью проблемы полихромии в теории скульптуры в целом.

Кратко продемонстрировав опыт использования полихромии в скульптуре на протяжении истории развития мировых культур, авторы на основе анализа современных скульптурных композиций делают выводы о востребованности и разнообразии использования средств полихромии в отечественной скульптуре двадцать первого века. Выделены две функции использования цвета в скульптуре, а именно имитации/оживления и символическая/сакральная. Характеристики данных функций рассмотрены на основе конкретных примеров, в заключение оценены перспективы развития полихромии как одного из самых выразительных композиционных приемов пластики.
\end{abstract}

Ключевые слова: полихромия, современная скульптура, станковая скульптура, цвет в скульптуре, семантика цвета, скульптурные материалы, функция имитации/ оживления, функция символическая/сакральная.

Научная специальность: 17.00.04 - изобразительное и декоративно-прикладное искусство и архитектура.

\section{Введение}

Любой скульптурный объект имеет свой цвет, тон, обусловленный выбранным материалом произведения. Собственный цвет скульптуры узнается в сопоставлении с фоном или средой, которые этот цвет подчеркивают. Скульптура, предшествовавшая европейской классике, была полихромной или, во всяком случае, не бесцветной не только за счет цвета материала, но и из-за специальной подкраски. Историк и теоретик искусства В.С. Турчин (1941-2015) считал, что цвет способен преображать традиционный материал пластики, поэтически одухотворять его (Vipper, 1970: 15).
Вопросы о роли и значении цвета в станковой скульптуре являются актуальными на протяжении многовековой истории развития отечественной и зарубежной пластики. Для современного мастера очевидно, что применение цвета в объемнопространственных видах изобразительного искусства сопряжено с опасностью нарушения целостного восприятия формы, поэтому он зачастую использует прием полихромии достаточно осторожно и взвешенно. Одновременно необходимо учитывать, что художественные качества цвета значительно выразительнее в сравнении с другими средствами композиции. Цвет оказывает более быстрое эмоциональное воздействие 
на воспринимающего произведение скульптуры зрителя, чем другие средства художественной выразительности, например силуэт, фактура, светотень.

\section{Постановка проблемы}

Полихромия в скульптуре нередко возникает в связи с усилением потребности человека (как художника, так и зрителя) в мифологическом и символико-дидактическом видении мира. Очевидно, что в отечественном культурном пространстве существует также связь с ремесленными традициями деревянной скульптуры, народными мотивами. Нередко потребность воздействовать цветом имеет религиозный и мистический подтекст. Примечательно, что наиболее ярко композиционные находки в работе с выразительными качествами цвета у отечественных мастеров проявляются в станковой скульптуре. Здесь мы видим настоящее поле экспериментов, однако в композициях городской среды полихромия не достигает подобных масштабов. Связано это с тем, что в станковом творчестве автор не скован техническими заданиями, архитектурным контекстом и пожеланиями заказчиков. В станковой скульптуре нет границ применения материала, а язык художественного высказывания сдерживают только личностные барьеры и степень дарования творца.

Обозначив выше наиболее существенные моменты, обратимся далее к практикам современных молодых скульпторов, выделим в их творческих исканиях произведения с использованием полихромии. Целью нашего исследования будет раскрытие современных возможностей использования цвета. На основе формально-стилистического метода с применением герменевтических и аналитических подходов проследим, каковы смыслы и функции современной полихромии, какие выразительные средства дают новые материалы.

\section{Обсуждение}

\section{Функция оживления/имитации}

Самым понятным и распространенным посылом для использования выразительных возможностей цвета в скульптуре с древности было стремление к оживлению и имитации. Рассмотрение данного аспекта следует начать с того факта, что скульптура была связана с охотничьей магией и погребальными ритуалами, где протоскульптура (упрощенные фигурки животных, фигурки-«заменители» человека) имела магический смысл и назначение, а цвет выполнял специфические сакральные функции. Огромное значение имел именно ритуал окрашивания/тонирования объекта. Так, например, посыпание краской изображений богов, что практикуется в Индии и Африке до сих пор, можно считать далеким отголоском древних магических актов, оживляющих его объемное подобие. В этом же ряду находится и ритуальное обсыпание краской всех прохожих с пожеланием здоровья и молодости во время индийского праздника Холи (Makovsky, 1996: 17). Во многих древних культурах (Китай, Двуречье, Индия, Доколумбовая Америка, Древний Египет) цвет выполнял функцию оживления. Важной задачей было создать эффект присутствия, пригласить божество или дух в созданное человеком вместилище.

Мастера Древней Греции расписывали тела фигур прозрачным цветным воском, пытаясь воссоздать прозрачность и трепет кожи. Демиурги использовали инкрустацию драгоценными камнями, создавая блеск глазниц. Со времени египетского портрета это связывалось с ритуалом «отверзания глаз и уст» для новой жизни в единстве тела и духа. Отсюда такое внимание к магическому натурализму в инкрустации драгоценными камнями глаз как врат бессмертия и символа духовной жизни (Нофрет и Рахотеп) (Makovsky, 1996: 20). От простой раскраски фигуры эти образцы отличает в высшей степени мастерство ремесленное, тонкость и деликатность в использовании материалов.

В эпоху Возрождения цвет применяется в майоликах семейства Роббиа и в нежных гармониях стуковых рельефов. Эпоха барокко поражает мастерством обработки материала, скульпторы сочетают различные породы камня, украшают цветными вставками надгробия и аллегорические фи- 
гуры. Отдельного упоминания заслуживает более поздний апологет полихромии Макс Клингер (1857-1920), который в программной работе «Бетховен» интегрирует такие разные материалы, как гипс, бронза и мрамор. Клингер ставил целью закрепить роль цвета в пластических искусствах в качестве звена на пути к синтезу искусств.

А. Гильдебранд в «Проблеме формы в изобразительных искусствах» (1893), дискутируя с теорией мимесиса, требовал от краски в скульптуре «антинатуралистичности», совпадающей с чистотой цвета естественного материала. Примечательно, что живописцы практиковавшиеся в скульптуре, зачастую раскрашивали свои работы: П. Гоген, Ф. Леже, Х. Миро, Х. Арп, Б. Бюффе, Ж. Дебюффе. Интерес к полихромии как выразительному качеству проявляли многие отечественные скульпторы, среди них А. Голубкина, Н. Андреев, В. Ватагин, советские мастера А. Пологова, Т. Каленкова, Н. Жилинская, В. Клыков, М.Воскресенская, старшее поколение российских скульпторов: А. Рукавишников, М. Переяс- лавец, Д. Тугаринов, М. Дронов, А. Ковальчук, С. Бычков.

Даже столь сжатый исторический экскурс показывает, насколько глубокое содержание вкладывалось в различные способы использования цвета в скульптурной пластике на протяжении веков. Поэтому особо актуально рассмотреть, как работает функция оживления/имитации в современных нам творениях.

Так, в модели М.В. Дронова «Петр I», выполненной для аэропорта Пулково, цвет становится средством коммуникации скульптурного объекта и зрителя. Осовремененный, чуть гротескный образ императора благодаря сочности оттенков становится дружелюбным, по-своему забавным. В творчестве такого заслуженного и высоко признанного художественным сообществом мастера, как Михаил Дронов, в последние два десятилетия полихромия постоянный композиционный инструмент. Огромная его заслуга в гуманизации, «очеловечивании» образов в ироничном, только ему присущем диалоге со зрителем.

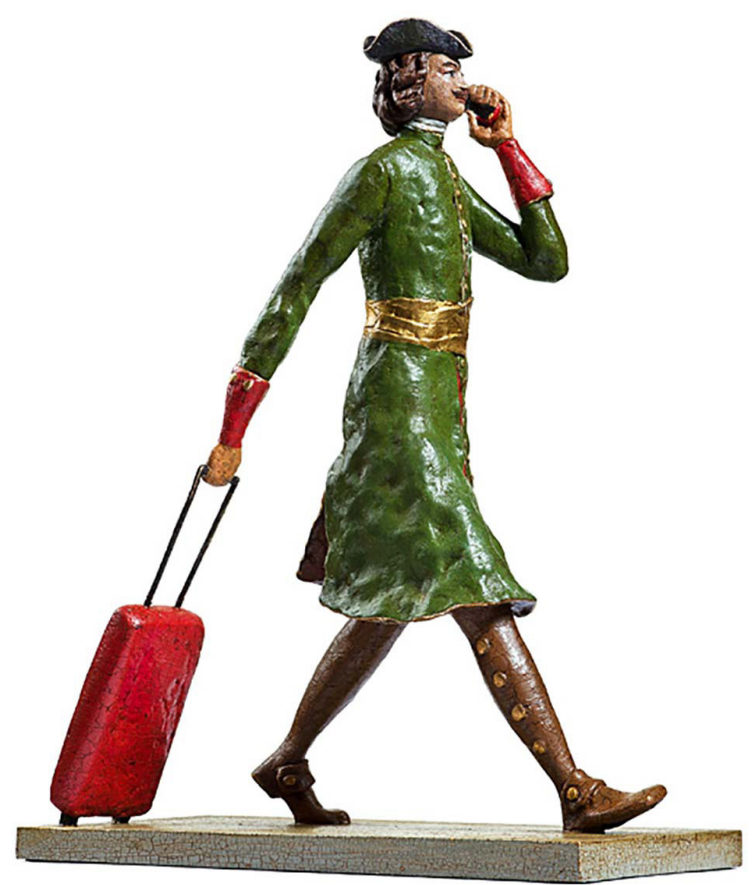

М. В. Дронов. Петр І. 2015. Бронза, тонировка. $39 \times 30,5 \times 14,5$ M. V. Dronov. Peter I. 2015. Bronze, toning. 39×30,5×14,5 


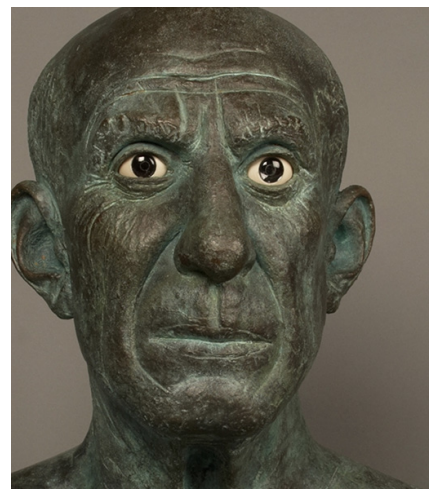

С.Г. Мильченко. Пикассо на корриде в Валлорисе. Фрагмент. 2006. Бронза: литье, инкрустация, кость, горный хрусталь, лабродолит. $41 \times 50 \times 28$

S. G. Milchenko. Picasso on Barda in Valloris. Fragment. 2006. Bronze: casting, inlay, bone, rhinestone, LABRODOLIT. $41 \times 50 \times 28$

Работы С. Г. Мильченко «Пикассо на корриде в Валлорисе» и С.В. Сережина «Портрет нубийца» - прямая реминисценция, отклик на римские портреты I в. до н. э. (портрет Цецилия Юкунда, Октавиана Августа), где используется упомянутая нами в историческом обзоре инкрустация.

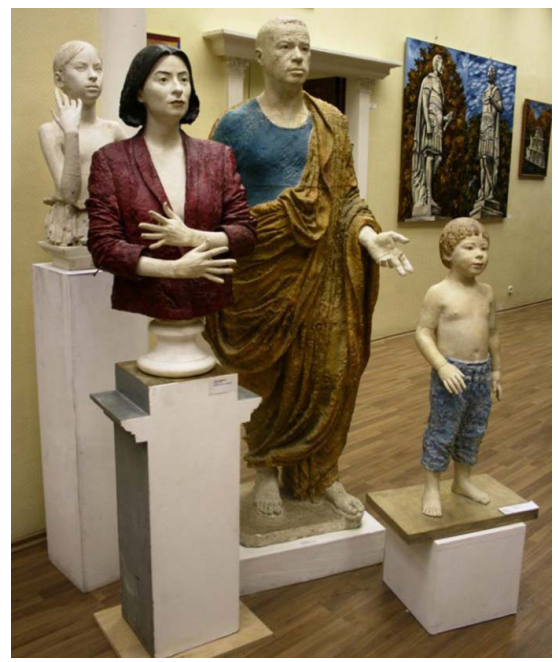

Фото экспозиции выставки «Современное искусство» Л. М. Баранова в Перми. 2015

Photo from exposure of the exhibition «Contemporary Art». L. M. Baranova in Perm. 2015

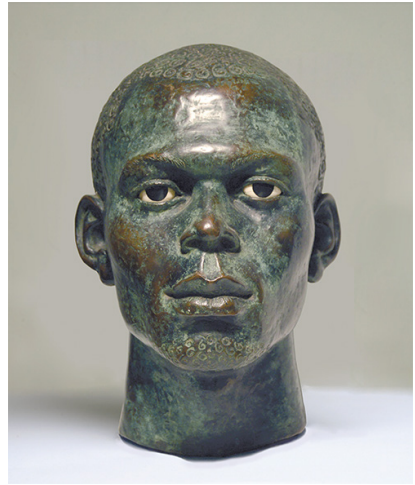

С. В. Сережин. Портрет нубийца. 2004. Бронза: литье, инкрустация. $71 \times 25 \times 30$

S.V. Serezhin. Portrait of a nubian. 2004. Bronze: casting, inlay. $71 \times 25 \times 30$

Это попытка продолжить данную традицию, возродить преемственность в начале третьего тысячелетия нашей эры. Но, безусловно, это не просто копирование приемов римских мастеров, работы звучат остро и современно, от беспощадного натурализма римлян авторы переходят к более философски насыщенной образности, перед нами действующие лица общечеловеческой истории со всеми ее экзистенциональными проблемами.

Собственную линию в экспериментах с полихромией ведет Н.Л. Баранова, наследница скульптурной школы семьи Леонида Баранова. Как пример рассмо-

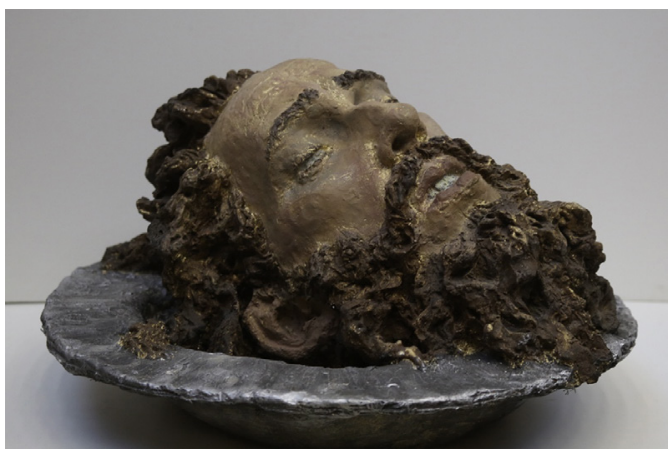

Н.Л. Баранова. Голова Иоанна Крестителя. 2016-2017. Гипс тонированный. 26x42×45

N. L. Baranova. Head of John the Baptist. 2016-2017. Gypsum tinted. 26×42×45 

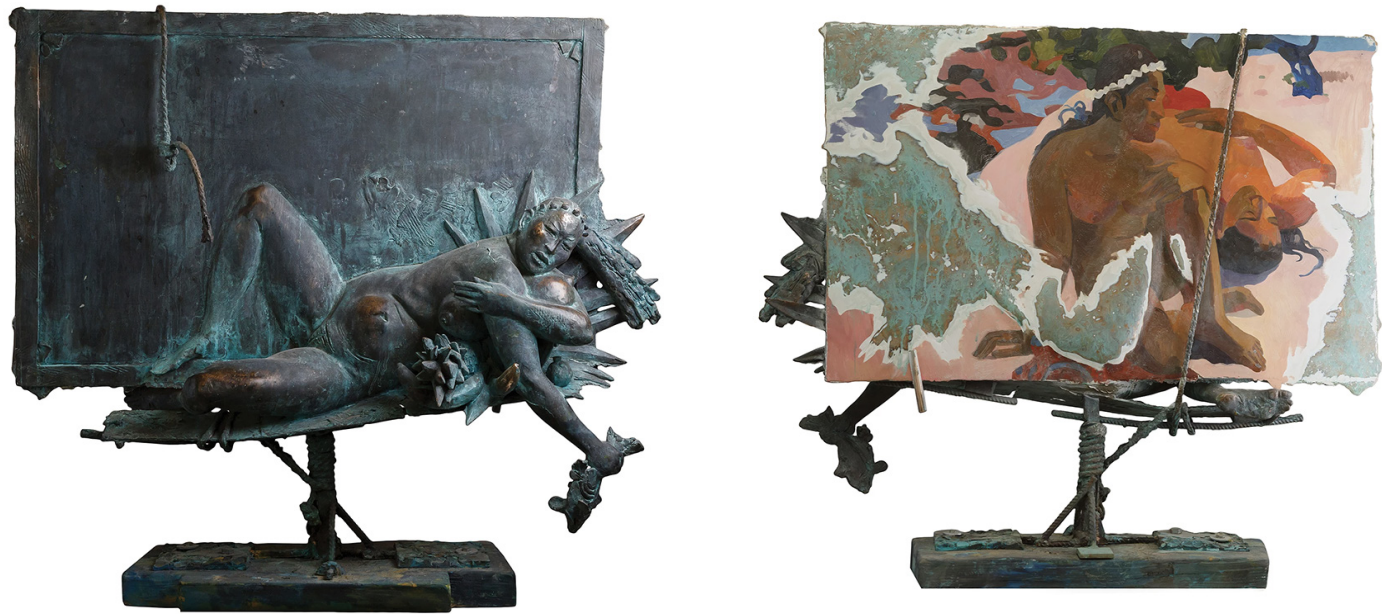

А.А. Миронов. Художник и модель. П. Гоген. 2017. Бронза, масло. 96×107x34 A. A. Mironov. Artist and model. P. Gogen. 2017. Bronze, oil. 96×107×34
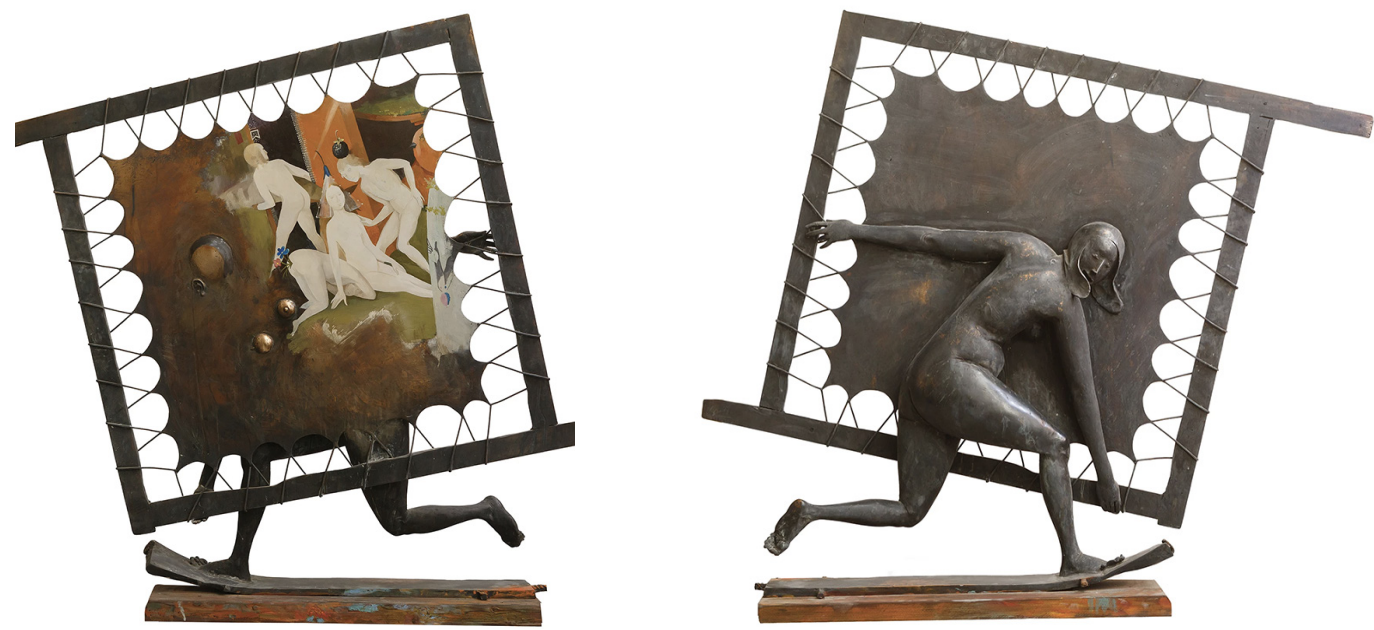

А.А. Миронов. Художник и модель. И. Босх. 2017. Бронза, масло. 110х125x25 A. A. Mironov. Artist and model. I. Bosch. 2017. Bronze, oil. 110x125×25

трим композицию «Голова Иоанна Крестителя», объект - «обманку», в котором именно цвет добавляет нужное звучание, подтверждает эффект присутствия, эффект реальности трагизма произошедшего. Как и прежде, знаком божественности становится блеск металла или имитация металлизированной краской, неслучайно полихромия наиболее стойко сохраняется на сакральных с точки зрения ритуала частях лица - глазах, реже губах, волосах, орнаменте одежды.
Отдельного внимания заслуживает серия Александра Миронова «Художник и модель» (2017, бронза, масло). За основу взяты мотивы известнейших работ П. Гогена, И. Босха, А. Модильяни, А. ТулузЛотрека. Творчество мастера сочетает высокопрофессиональную академическую школу с постоянным экспериментом как по темам и образам, так и по способам их воплощения. Все вместе пример согласованного сочетания собственно скульптурной пластики с живописным воздей- 

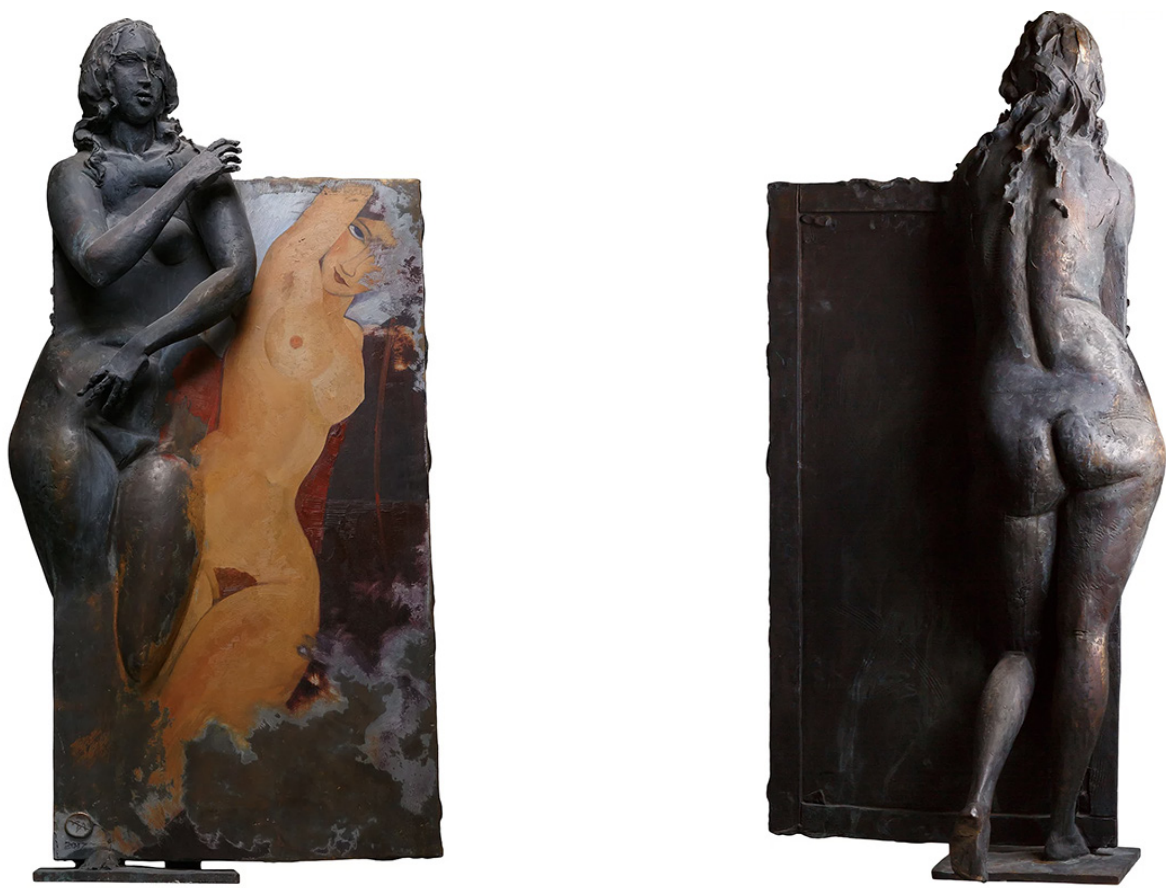

А.А. Миронов. Художник и модель. А. Модильяни. 2017. Бронза, масло.117×57x27 A. A. Mironov. Artist and model. A. Modigliani. 2017. Bronze, oil.117×57×27
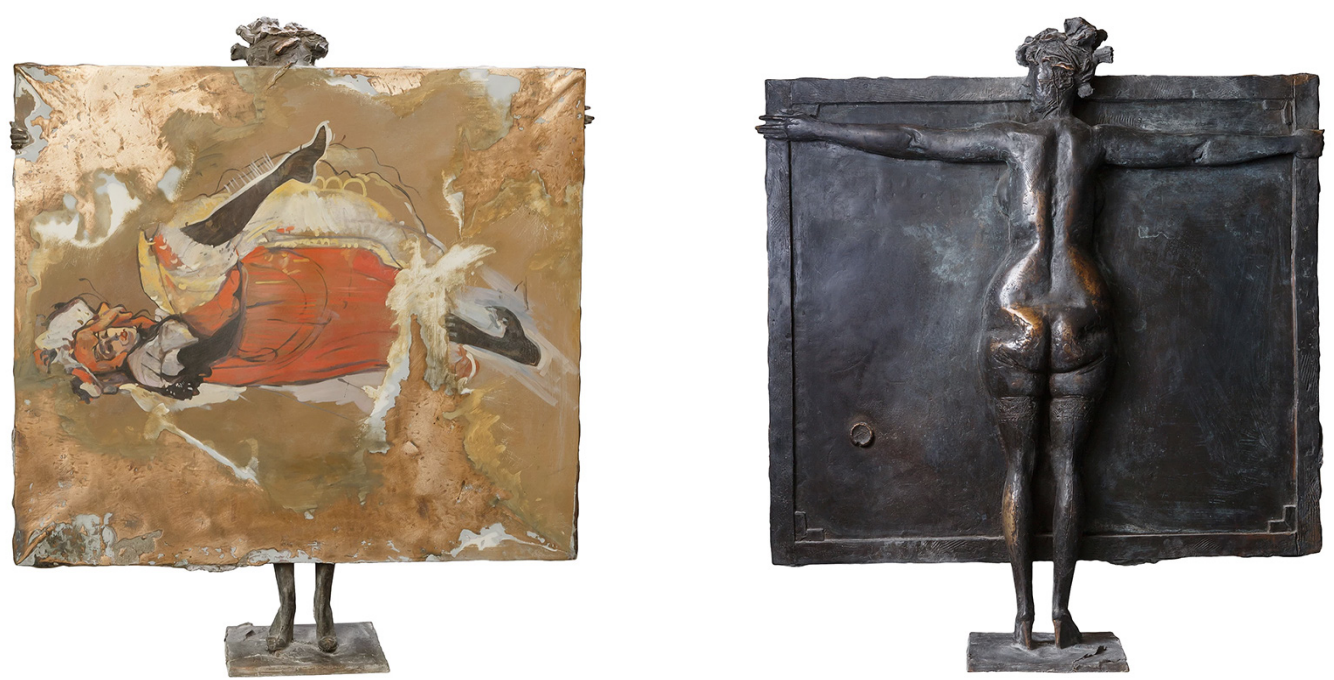

А.А. Миронов. Художник и модель. А. Тулуз-Лотрек. 2017. Бронза, масло. 117×107x27 A. A. Mironov. Artist and model. A. Toulouse-Lotrek. 2017. Bronze, oil. 117×107×27 
ствием цвета, обогащенного стилизацией под живопись. Серия дает современный взгляд на решение спора о возможностях цвета в скульптуре, выделяется гармоничной вариативностью и свободой в композиции (Bel'skiy, 2018).

Таким образом, мы видим, что тенденция «оживлять» скульптурный объем или «имитировать» в какой-то мере цвет натуры сохраняется и развивается, создает новые комбинации цвета и формы.

\section{Символическая/сакральная функция}

Следует отметить, что в данном случае активно включается семантика цвета, a данные исторической этимологии дают научно подтвержденный подробный спектр символического значения краски и цвета (Makovsky, 2006: 23). М.М. Маковский считает, что цветовые характеристики являются свойством, имманентно присущим животному миру, знаком его жизненной энергии. «Мистическая символика краски возникла на основе хроматических оттенков жертвенного огня. Причем первоначально индоевропейцы считали основными только три краски: белую (символ неба как потустороннего мира, по которому путешествуют души умерших), черную (символ преисподней) и красную (символ божества, жизни, очищения)» (Klark, 2002: 52).

В ритуальном искусстве предшествующих эпох окраска могла символизировать не только сущность, но и отношения. Символика цвета не была произвольной. Для понимания подобного феномена в современной пластике коротко остановимся на исторических примерах древних культур, в которых это присутствует в изобилии.

В Древнем Египте Анубис, хранитель и проводник загробного мира, неизменно изображается черным, а его божественная сущность индексируется золотом. Скарабей, ежедневно выкатывающий из-под земли золотой шар солнца на просторы неба, синего, небесного цвета. Божество ацтекского пантеона Кетцалькоатль - змей, покрытый зелеными перьями, владыка стихий и бог утренней звезды, как небесный бог был окрашен в голубой или зеленый цвета, которые в древности принципиально не различали. Черный лик и красная терракота архаической фигуры Аполлона из Вей (Этрурия) - свидетельство о первичной хтонической природе божества (Domogatsky, 1984: 19). Примеры можно множить, важно обозначить, что для древних скульпторов цвет имел прямое отношение к изображаемому, не был чем-то внешним или декоративным.

Обратимся к современным образцам. В работах И.А. Козлова «Спас Полуношный» и «Зеленый Ангел» приглушенный лазурный зеленый обогащает небесные образы. «Спас Полуношный» отсылает к традициям пермской скульптуры, цвет приглушенный, словно ночной, мерцающий, создающий мягкий эффект. Это современное прочтение сюжета «Гефсиманского сада» в знаковой, целостной форме. В работе «Ангел» именно цвет дополняет тектоничность, цельность, подсказывая неземное значение образа.

Существуют и чистые эксперименты в области тонировки. Как, например, в работах «Белая лошадь» и «Синяя лошадь» А.Л. Дмитриева. Автор даже не прибегает к патинированию, используя современный ему акрил. «Небесный конь», «Белый конь» уже устоявшиеся архаичные образы, поэтому выбор цвета обусловлен содержанием образа. Интересно в этих работах то, как органично сочетаются цвет и форма, превращаясь в знак. Стоит отметить оригинальное фактурное решение в «Синей лошади». Оставленные следы литников, неравномерность тонирования отсылают к итальянской пластике XX в. В работе «Зима» используется белый цвет, тонированный оксидом железа. «Лето» традиционно для русского фольклора и языка красное. Ключница «Осень» - это сочетание пластики и собственного цвета дерева: теплого, золотистого.

В работе Е.М. Суровцевой «Вера. Надежда. Любовь» красный цвет отсылает к фовистским поискам А. Матисса. Плоскостность и линейность предложенной работы выступают визуальным манифе- 


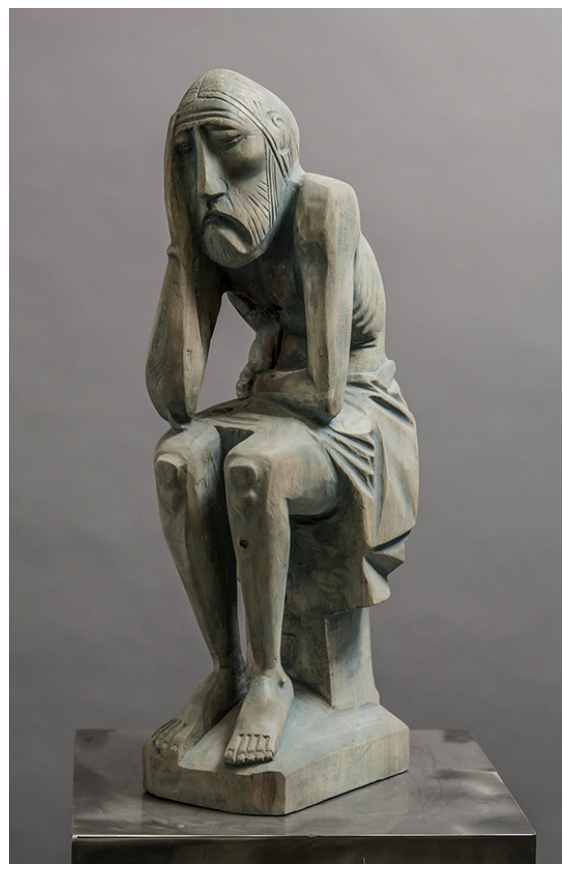

И.А. Козлов. Спас Полуношный. 2006. Дерево: тонировка. 50×11×19

I. A. Kozlov. Spas Semi-dry. 2006. Wood: Toning. 50x11×19

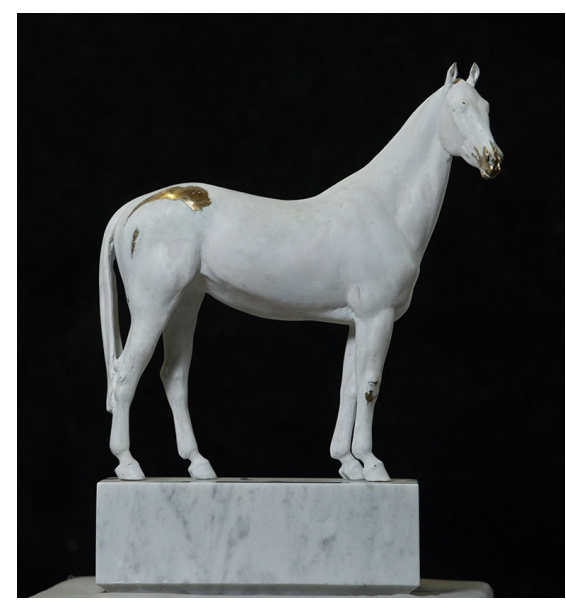

А. Л. Дмитриев. Белая лошадь. 2017. Бронза, мрамор, акрил. 50×39×10

A.L. Dmitriev. White horse. 2017.

Bronze, marble, acrylic. 50×39×10

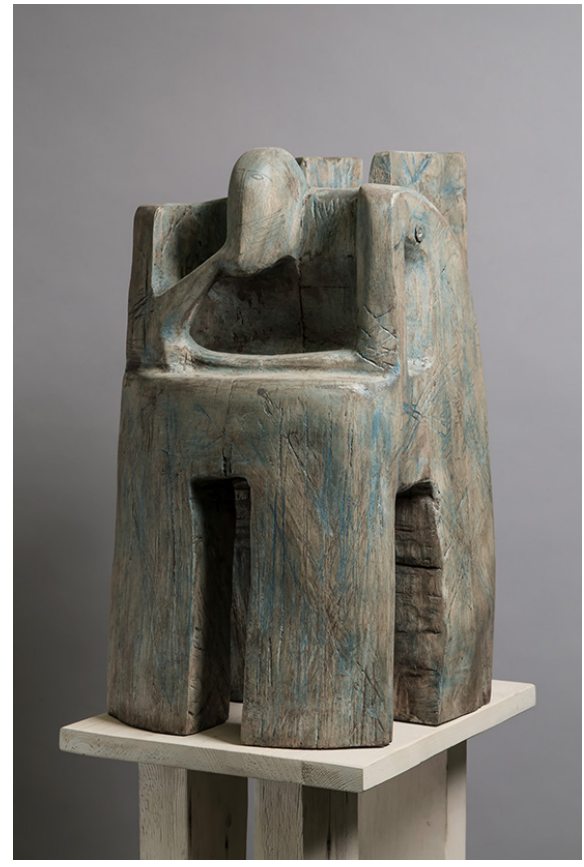

И.А. Козлов. Зеленый Ангел. 2007. Дерево: тонировка. $45 \times 21 \times 30$

I. A. Kozlov. Green Angel. 2007. Wood: Toning. $45 \times 21 \times 30$

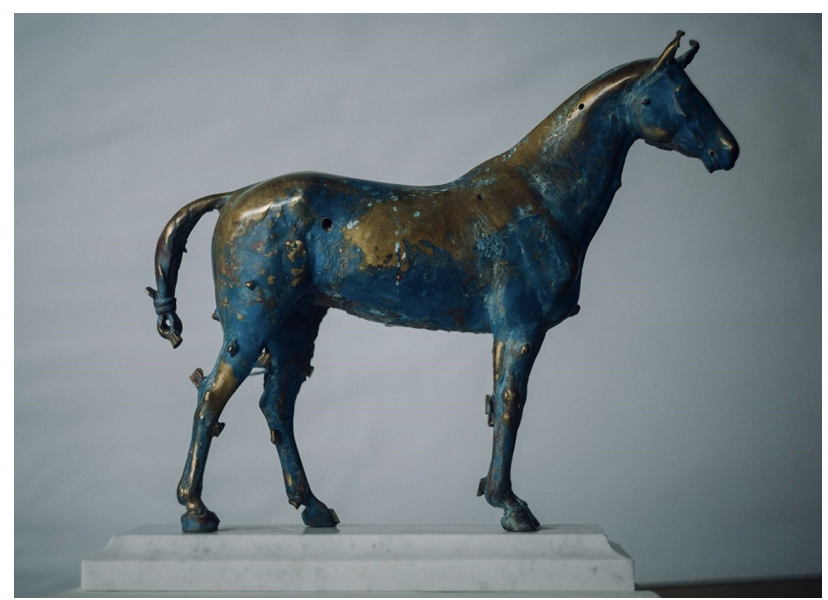

А. Л. Дмитриев. Синяя лошадь. 2016. Бронза, дерево, акрил. 40×46×11

A. L. Dmitriev. Blue Horse. 2016. Bronze, wood, acrylic. 40×46×11 


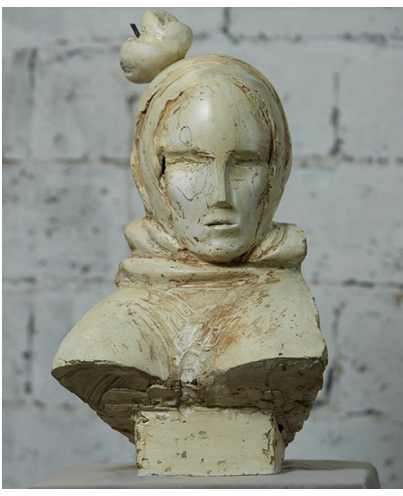

А.Л. Дмитриев. Ключница. Зима. 2015. Гипс, железо. $60 \times 33 \times 35$

A. L. Dmitriev. Housekeeper. Winter. 2015.

Gypsum, iron. $60 \times 33 \times 35$

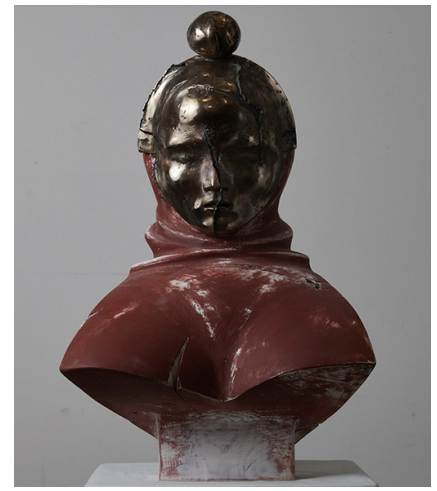

А.Л. Дмитриев. Ключница. Лето. 2017. Дерево, бронза, акрил. $72 \times 48 \times 40$

A. L. Dmitriev. Housekeeper. Summer. 2017. Wood, bronze, acrylic. $72 \times 48 \times 40$

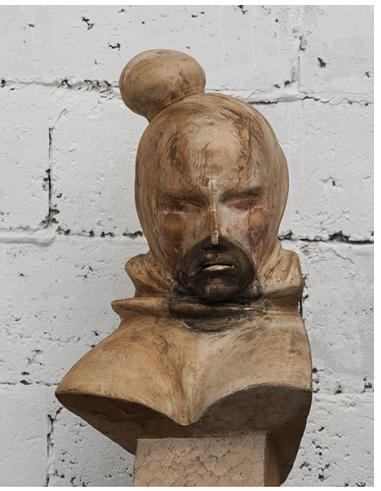

А.Л. Дмитриев. Ключница. Осень. 2016. Дерево, бронза, старинный ключ. $60 \times 33 \times 33$

A. L. Dmitriev. Housekeeper. Autumn. 2016. Wood, bronze, vintage key. $60 \times 33 \times 33$

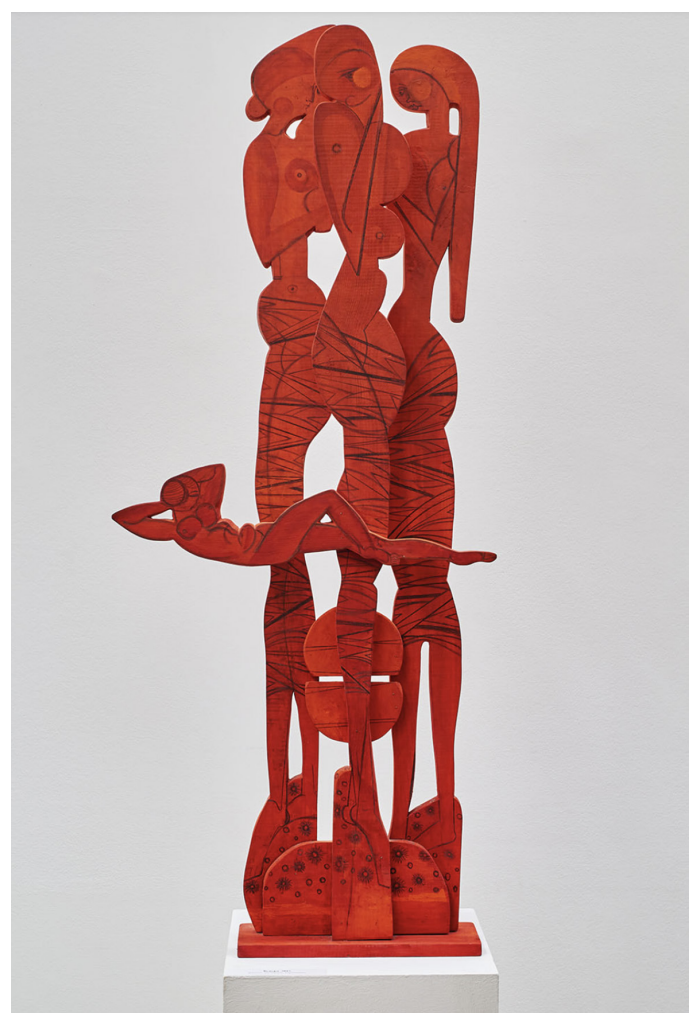

Е. М. Суровцева. Вера. Надежда. Любовь. 2018. Дерево, тонировка

E. M. Surovtseva. Faith. Hope. Love. 2018. Wood, Toning 
стом «Новых диких» в скульптуре. Жизнеутверждающая мощь красного цвета звучит символ энергии и вызова.

Обратимся также к двум портретам «Валентина» Ю.Г. Нероды и «Зигмунд Фрейд» Ю. Ю. Нероды. В работах мастеров двух поколений используется пластмасса, относительно новый материал с точки зрения скульптурной практики. Материал, раскрывающий большие возможности тонировки, цветовых эффектов и декорирования поверхности. Портрет Валентины Терешковой, новаторский для 1960-х гг., где материал тонирован в массе, а красный как символ активности. У сына скульптора заметно влияние отца, используется аналогично оргстекло как подставка, но уже в другом пространстве пластики (Rid, 2018: 7).

И, наконец, чуть подробнее остановимся на том, как используется цвет в творчестве Д.Б. Намдакова. Работа «Слоник» отсылает к легкому, небесному. Возникает символическая ассоциация с «Дамбо». «Его большие уши похожи на крылья, все тельце устремлено вперед, а задние ноги будто вотвот оторвутся от земли, и слоник взлетит! Голубая патина лишь подчеркивает необычность персонажа, его наивность и романтизм, а образ малыша вызывает самые добрые чувства» (Interviu Dashi Namdakova, 2021). Голубой не является собственным

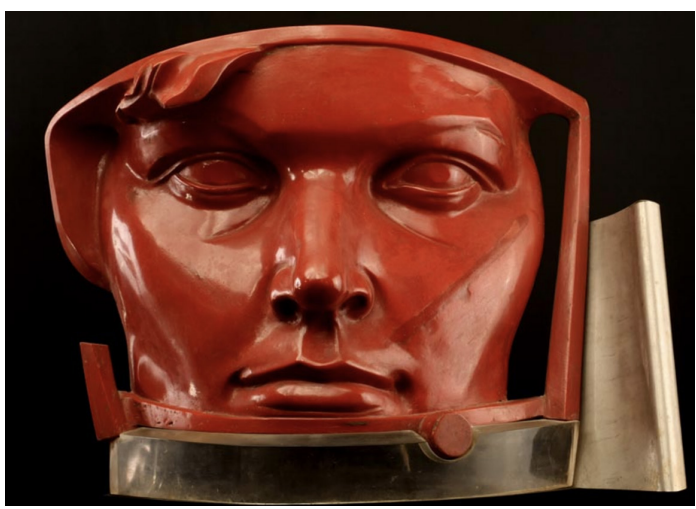

Ю.Г. Нерода. Валентина. 1964. Пластмасса, оргстекло, алюминий. Высота 50

Yu. G. Neroda. Valentine. 1964 Plastics, Plexiglas, Aluminum. Height 50 цветом слоника, это не есть подражание, имитация, но ассоциативно связывается у воспринимающего скульптуру с легкостью, с устремленностью в небеса.

В работе «Схватка» собственно цветом является цвет природного камня и золочение. Золото и лазурь - цветовая пара, которую можно проследить прежде всего в искусстве Древнего Египта (посмертная маска Тутанхамона), где по выражению Р. Кларк, этот тандем есть последняя стадия «пресуществления тела в божественную субстанцию», существующую среди «неуничтожимых полярных звезд». Золото - важнейший материал для скифской культуры. Не случайно для центрального мотива схватки двух противодействующих сил скифской космологии выбраны эти цвета. Декоративный эффект усиливает великолепно выполненная резчиком по камню работа в материале, что, по мнению Намдакова, вызвано его пребыванием в Италии (Interviu A. Mironova, 2021).

Флагманской работой серии «Изнутри» стала «Энергия», в которой Даши использует классическую цветовую триаду, за исключением белого, роль которого восполняет золото. В пояснении к работе говорится: «Торс, в котором можно увидеть как

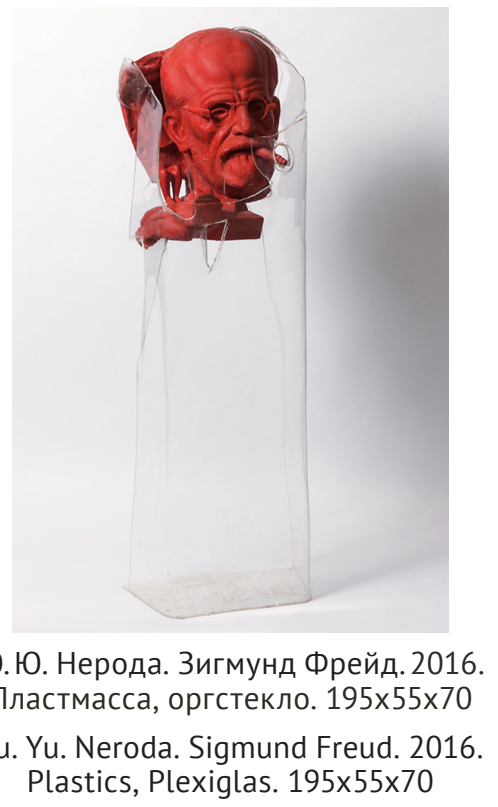




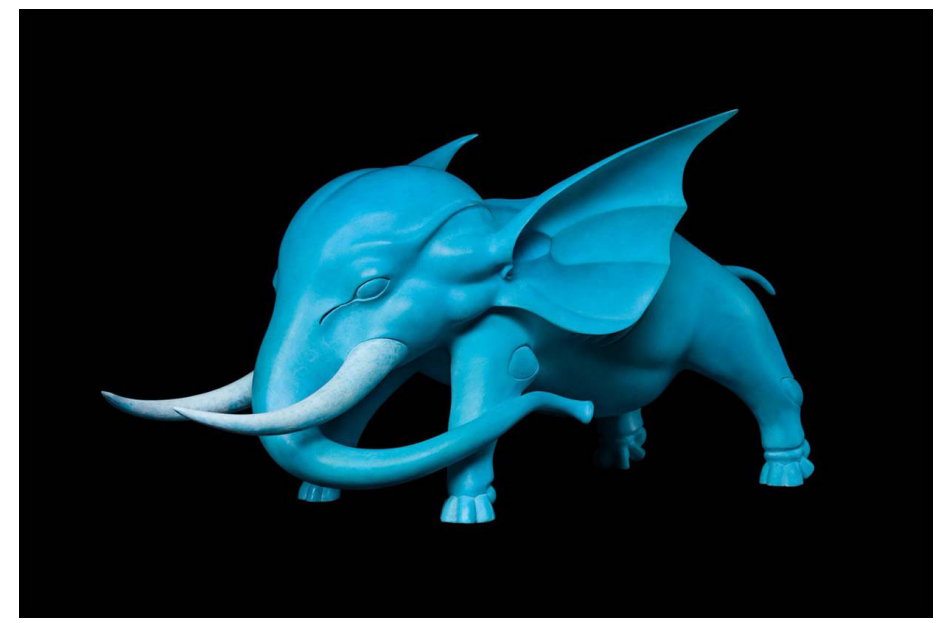

Д.Б. Намдаков. Слоник. 2014. Бронза; литье, патинирование. 35×75×37

D. B. Namdakov. Elephant. 2014. Bronze; Casting, patination. 35×75×37

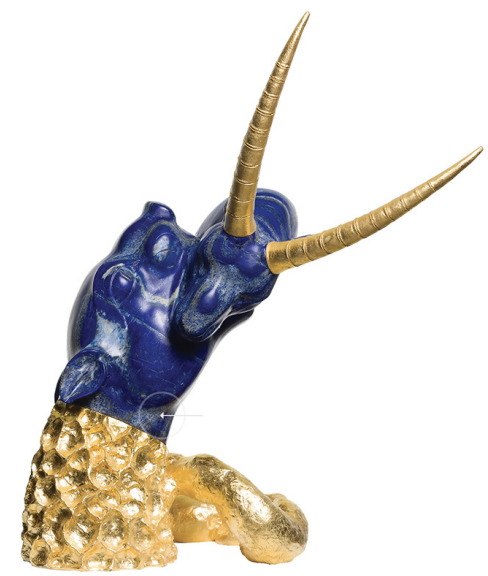

Д. Б. Намдаков. Схватка. 2014. Лазурит: резьба; бронза: литье, золочение. 75×38×28

D. B. Namdakov. Fight. 2014. Laps: carving; Bronze: casting, gilding. $75 \times 38 \times 28$

антропоморфные, так и зооморфные очертания, - это, с одной стороны, реминисценции ко всей истории искусства, начиная с Бельведерского торса, с другой стороны, личная отсылка к каждому из зрителей любого пола и возраста. Что произошло с этим существом, что заставило его принять эту мучительную позу? Изнутри он сияет на зрителя невероятными цветами - его внутреннее победило его внешнее, его ждет перерождение в новую, сияющую форму» (Sait Dashi Namdakova, 2021). 


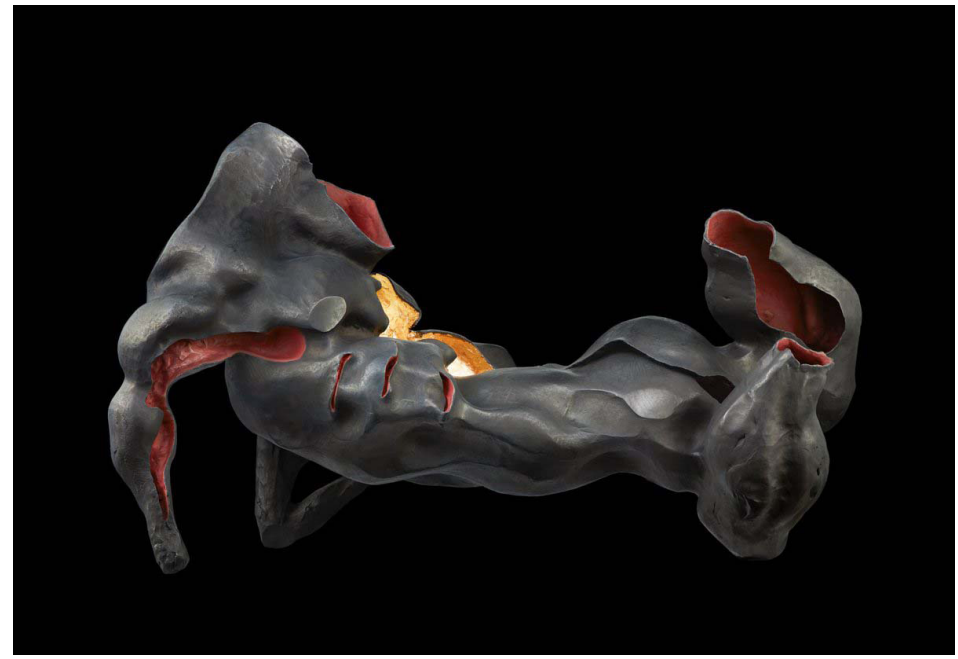

Д. Б. Намдаков. Энергия. 2018. Бронза; литье, патинирование. 88x152x74 D. B. Namdakov. Energy. 2018. Bronze; Casting, patination. 88x152x74

\section{Заключение}

Кратко рассмотрев опыт полихромии в скульптуре на протяжении истории развития мировых культур и проанализировав композиции с различными приемами использования цвета российских авторов, выполненные в последние двадцать лет, отметим, что полихромия в скульптуре - это вполне современное явление, год за годом вызывающее все больший интерес и скульпторов, и зрителей. Развитие этого явления в российском ваянии опирается на особое понимание авторами принципов станкового искусства. Особенно пристально мастерами изучается древнерусская скульптура, наследие древних цивилизаций, античность. Каждый из скульпторов видит возможности взаимодействия пространственных видов искусства и цвета сугубо индивидуально, извлекая эмоционально-экспрессивные, метафорические или декоративные эффекты воздействия. Цвет становится инструментом, символом или украшением, являясь обязательным звеном синтеза искусств и включаясь неотъемлемой частью в содержательное и эмоциональное звучание образа.

С древнейших времен до сегодняшнего дня основополагающие посылы к использованию полихромии можно разделить на две большие группы: функция оживления/имитации и символическое/ мифологическое значение цвета. Перспективы дальнейшего развития полихромии обусловлены тем, что в творчестве художников она становится одним из самых выразительных композиционных приемов пластики. Также подчеркнем, что тема использования цвета в скульптуре ждет дальнейшей разработки и детализации. Особенно интересно проследить, как семиотика и философия полихромии, заложенные в древности, проявляются и развиваются в современных практиках отечественных скульпторов в контексте не только столичного, но и регионального художественного процесса.

\section{Список литературы / References}

Avsiyan, A.O. (1996). Iskusstvo kompozicii [The Art of composition]. Moscow, Zvonnica-MG, 222 p. Turchin, V.S. (1974). Tsvet v sculpture [Color in sculpture]. In Tvorchestvo [Tворчество], 11, 15-19. Vipper, B.R. (1970). Stat'I ob iskusstve [Articles about art]. Moscow, Iscusstvo, 591 p. 
Vlasov, V.G. (2017). Teoreticheskiye raboti. Issledovaniya, stat'i. Pisma hudozhnika [The theory of shaping in the visual arts: textbook]. S-Pb, Isdatel'stvo S-Peterb. Un-ta, $264 \mathrm{p}$.

Domogatsky, V.N. (1984). Teoriya formoobrazovaniya v isobrazitel'nom iskusstve: uchebnik [Theoretical works. Research, articles. Artist's Letters]. Moscow, Sovetskiy hudozhnik, 368 p.

Istoriya iskusstv. Perviye civilizacii (1998). [The history of art. The first civilizations] ZAO BetaServis [CAS Beta-Service],220 p.

Klark, R. (2002). Svechenniye tradizii Drevnego Egipta [Sacred traditions of Ancient Egypt]. Moscow, GRAND: fair-press, $100 \mathrm{p}$.

Makovsky, M.M. (2006). Fenomen tabu v tradiziiah I yazike indoevropeytsev, suchnost'-formi-razvitie [The phenomenon of taboo in the Traditions and language of Indo-Europeans: essence-forms-development]. Moscow, KomKniga, 280 p.

Makovsky, M.M. (1996). Sravnitel'niy slovar' mifologocheskoy simvoliki v indoevropeiskih yazikah: Obraz mira i obrazi mirov [Comparative Dictionary of Mythological symbolism in Indo-European languages: The Image of the World and the worlds of images].Moscow, Gumanit. izd. Centra VLADOS, $416 \mathrm{p}$.

Medkova, E.S. (2015). Perezhivanie sculpture. Tsykl lekziy ob istorii scul'ptury, sposoba ieio vospriiatiia, materiale, tsvete, forme [Experiencing sculpture. A series of lectures on the history of sculpture, the way it is perceived, material, color and shape], In Iskusstvo. Pervoe sentiabria [Art. First of September], $4-11,28-40$.

Rid, G. (2018). Kratkaya istoriya sovremennoi sculpturi [Short History of Modern Sculpture].Moscow, Iscusstvo-XXI vek, $240 \mathrm{p}$.

Bel'skiy P., Nikolaeva E. (2018). Plasticheskaya massa: scul'ptura vtoroi polovini XX nachala XXI veka [Plastic mass: Russian sculpture of the second half of the XX - beginning of the XXI century], In Russkiy Musey predsavliaet [Russian Russian Museum presents], 533, 96.

Interviu Dashi Namdakova (2021). Vstrecha so studentami SGII im.D. Hvoristovskogo [Interview with D. Namdakov. Meeting with students of the SSAoA named after D. Hvorostovsky] (accessed 16 March 2021).

Interviu A. Mironova (2021). Inrerviu v masterskoi hudozhnika. [Interview in the artist's studio], available at: https://www.youtube.com/watch?v=U023R4TGxJA (accessed 15 August 2021).

Sait Dashi Namdakova (2021). [Dashi Namdakov's website], available at: https://dashi-art.com/gallery/ sculptures/little-elephant (accessed 25 August 2021). 